\title{
From restrained golden age to creeping platinum age: A periodization of Latin American development in the Robinsonian tradition*
}

\author{
Da Idade do Ouro a Era Platinum Rastejante: uma periodização \\ do desenvolvimento Latino Americano na tradição Robinsoniana
}

MATÍAS VERNENGO**

\begin{abstract}
RESUMO: Este artigo analisa o modelo de crescimento de Joan Robinson, aqui adaptado a fim de fornecer uma taxonomia exploratória de Eras de Crescimento. Essas Eras ou Anos de Crescimento foram para Robinson uma maneira de fornecer conexões lógicas entre o crescimento da produção, a acumulação de capital, o grau de frugalidade, o salário real e ilustrar um catálogo de possibilidades de crescimento. Esta taxonomia modificada segue o espírito da obra de Robinson, mas é preciso diferentes abordagens teóricas, o que implica que algumas não se encaixam perfeitamente às aqui sugeridas. A América Latina passou de uma Idade de Ouro na década de 1950 e 1960, a uma Idade de Chumbo na década de 1980, com dois períodos de travessia, um em que o processo de crescimento e industrialização se acelerou na década de 1960 e início de 1970, que aqui se refere a uma Era Platinum Galopante, e aquela em que um processo de desindustrialização e reprimarização e maquilação da estrutura produtiva teve lugar, começando na década de 1990, que poderia ser referido como uma Era Platinum Rastejante.

PALAVRAS-CHAVE: desenvolvimento econômico; América Latina; modelos de crescimento heterodoxos.
\end{abstract}

ABSTRACT: This paper analyzes Joan Robinson's growth model, and then adapted in order to provide an exploratory taxonomy of Growth Eras. The Growth Eras or Ages were for Robinson a way to provide logical connections among output growth, capital accumulation, the degree of thriftiness, the real wage and illustrate a catalogue of growth possibilities. This modified taxonomy follows the spirit of Robinson's work, but it takes different theoretical

\footnotetext{
* The author would like to thank without implicating to Carlos Alberto Fuentes, Esteban Pérez Caldentey, Jürgen Weller and an anonymous referee from the Economic Commission for Latin America and the Caribbean (ECLAC) for their comments to a preliminary version.

** Full Professor, Bucknell University, e-mail: m.vernengo@bucknell.edu. Submetido: 8/setembro/2014; Aprovado: 9/outubro/2014.
} 
approaches, which imply that some of her classifications do not fit perfectly the ones here suggested. Latin America has moved from a Golden Age in the 1950s and 1960s, to a Leaden Age in the 1980s, having two traverse periods, one in which the process of growth and industrialization accelerated in the late 1960s and early 1970s, which is here referred to as a Galloping Platinum Age, and one in which a process of deindustrialization, and reprimarization and maquilization of the productive structure took place, starting in the 1990s, which could be referred to as a Creeping Platinum Age.

KEYWORDS: economic development; Latin America; heterodox growth models.

JEL Classification: O11; O54; E12.

\section{INTRODUCTION}

Joan Robinson's growth model is the basis of a whole set of demand driven explanations for economic development, which emphasize the interaction of population growth, and the inter-sectoral or structural transformation of the economy. Robinson's explicit objective was to extend Keynes' Principle of Effective Demand to the long run. In other words, she wanted to show that once the model allowed for capital accumulation, rather than fixed capital, the Keynesian notion that autonomous demand governed the determination of output, translated into the notion that autonomous spending, mainly investment in her view, was the driving force of the process of economic growth. ${ }^{1}$

The Robinsonian model, however, maintains an independent investment function, that relies on the 'animal spirits' of the capitalists to promote investment and economic growth, in Keynesian fashion. ${ }^{2}$ In this sense, there is a connection between the Robinsonian notion of a Leaden Age - in which the desired rate of capital accumulation is below the capacity limit of the economy, and under accumulation leads to low levels of technical change, unemployment and the persistence of underdevelopment - with the Old Dependency School notions about the absence of a dynamic entrepreneurial class in Latin America, as one of the reasons for underdevelopment. ${ }^{3}$

In Robinson's analysis the process of capitalist accumulation could confront several limitations beyond the lack of animal spirits, which would derail economic

\footnotetext{
${ }^{1}$ For a discussion of the limits of her approach, in comparison with Kaldor in particular, see Vernengo and Rochon (2001). The vast literature in the Robinsonian growth model is discussed in that paper, and we refer those interested in the detail to read it.

${ }^{2}$ It is worth noticing that the emphasis on an independent investment function, and on 'animal spirits' and expectations approximate some Keynesian analyses from Schumpeterian notions about the role of the entrepreneur as an innovator, even if the latter put more emphasis in the process of technological innovation implicit in investment decisions. For example, Dosi et al. (2010) try to emphasize the common elements in Keynes and Schumpeter's models.

${ }^{3}$ For a critical analysis of the contributions of the Dependency School see Vernengo (2006a).
} 
development. Economic growth beyond the rate of growth of the labor force, and the ensuing inflation barrier could also derail the economy, a situation in which she argued, contrary to the conventional Keynesian idea of the paradox of thrift, that higher savings would allow for increased capital accumulation.

In this paper the Robinsonian model is first criticized, and then readapted in order to provide an exploratory taxonomy of Growth Eras. Note that the Growth Eras or Ages were for Robinson a way to provide logical connections among output growth, capital accumulation, the degree of thriftiness, the real wage and illustrate a catalogue of growth possibilities. This modified taxonomy follows the spirit of Robinson's work, but it takes different theoretical approaches, which imply that some of her classifications do not fit perfectly the ones here suggested. ${ }^{4}$

The rest of the paper is divided in four sections. The first section indicates some limitations of the original Robinsonian taxonomy in particular in light of the differences between advances or central economies and peripheral ones. The next one provides a Kaldorian inspired version of Joan Robinson's taxonomy. The third section deals with the issue of income distribution and the taxonomy of growth, with particular emphasis on the last decade, in which Latin America has experienced a significant improvement in inequality measures. The final section provides a few concluding remarks.

\section{AN ADAPTATION OF THE ROBINSONIAN MODEL FOR THE PERIPHERY}

The basis of the Robinsonian theory of capital accumulation is the interaction of investment and profits. Investment determines profits through the multiplier mechanism, encapsulated in the Golden Rule, and profits, actually expected profits, in turn, determine investment. The feedback from profits to investment can be seen as a variation of the accelerator mechanism, which suggests that investment responds to higher levels of demand, and profits would be an indicator for firms of increasing sales. Although in the Robinsonian model the interpretation of the independent investment function was not on the basis of an accelerator, but on the basis of the Keynesian notion of animal spirits, with an emphasis on the entrepreneurial will to invest. As in the Harrodian model, the multiplier-accelerator interaction in Robinson's model leads to growth rather than cyclical fluctuation, in contrast to Kalecki's theory, something that is fundamentally dependent on the absance of time lags and the value of the parameters.

In Keynesian fashion, the desired rate of capital accumulation might be, by coincidence, the same as the rate of growth of the labor force, in which case the economy would be in what Robinson (1956, p. 173) referred to as the Golden Age, but there is no mechanism, as in Solow's theory, to guarantee that the path of ac-

\footnotetext{
${ }^{4}$ For a formal version of the accumulation model which inspires this taxonomy of Growth Ages see Pérez Caldentey and Vernengo (2013).
} 
cumulation would guarantee full employment. In the case that the rate of growth of the labor force superseded the desired level of capacity utilization, a Leaden Age would take place, in which workers were not incorporated in formal labor markets, increasing the level of disguised unemployment. In more dynamic economies, in which the labor force grew at a slower pace than the anticipated capital accumulation the economy would be classified as being in a Restrained Golden Age.

The Restrained Golden Age would be typical of any fast growing developing economy in the process of catching up with advanced economies. Robinson, however, also understood that the structural transformation of the economy was central to understand the process of capital accumulation. In particular, Robinson was concerned with the fact that the desired rate of capital accumulation required certain proportionality between the capital and consumption goods sectors, a preoccupation that was derived from Marx's schemes of reproduction and Kalecki's influence on her thinking. ${ }^{5}$ The Robinsonian growth model presumes that if the desired growth rate is below the one at which the actual capital stock is growing, then the capital goods sector would have to shrink over time, and there would be a transition from a steady-state with a relatively large to one with a comparatively small capital goods sector. This 'traverse' would be in her terminology a Creeping Platinum Age. In contradistinction, if the required rate of growth was higher than the current rate of growth of the capital goods sector, the latter would have to expand in comparison to the consumer goods sector, in order to maintain the required proportion. The latter case would be a Galloping Platinum Age, one in which the capital goods sector expanded, and that the Structuralist economists at the Economic Commission for Latin American and the Caribbean (ECLAC) referred to as the hard-phase of the industrialization process.

Some of the modern Kaleckian-Robinsonian models, following Bhaduri and Marglin (1990) assume that, besides the profit share, investment is affected by capacity utilization, and on this basis make the case for the possibility of alternative impacts of income distribution on the level of activity, namely: a profit-led and a wage-led growth regime. Contrary to the views of Kalecki and earlier Kaleckian models (e.g., Rowthorn, 1981) they argue that a rise in the profit share serves as the stimulus to investment and growth, whereas a wage led growth regime may fail to generate the required growth in productive capacity. The arguments in favor of profit-led growth are further reinforced by open economy considerations where wages increases are seen as damaging to competitiveness (Blecker, 1989). ${ }^{6}$

It must be noted that the Neo-Kaleckian models allow a limited role for de-

\footnotetext{
${ }^{5}$ In fact, in the literature the models that are clearly in the tradition of Robinson are often referred to as Kaleckian, following Rowthorn (1981). For a more recent discussion see Taylor (2004).

${ }^{6}$ In the Post Keynesian literature the investment function is generally expressed as a function of capacity utilization and profits, and by assumption the models have spare capacity (e.g., Taylor, 1985; Dutt, 1990; Bhaduri and Marglin, 1990; Lavoie, 1992). Kaldor, particularly in his post-1960s models, used the accelerator as the mechanism by which capital adjusted to the long term components of autonomous demand, what was referred to as the supermultiplier (Kaldor, 1970). Kaldorian models, following Thirlwall
} 
mand and it is on this basis that the case for profit-led growth rests. In particular, the profit share component of investment represents supply side forces which tend to predominate over the accelerator which reflect demand side factors. Kaldorian models, which emphasize the role of capacity utilization and place the emphasis on the accelerator rather than profitability, provide an endogenous solution for the question of the proportionality between the capital and consumption goods sectors. The accelerator suggests that investment, and, hence, the capital stock, adjusts to the level of demand, and as a result a normal capital to output ratio should prevail in the long run. That was the basis of Kaldor's famous stylized fact about a relatively constant ratio between these two variables.

In other words, investment is considered part of derived demand. The level of investment is ruled by the adjustment of capacity to exogenous demand, which, in turn, determines the normal level of capacity utilization. Note that in Joan Robinson's classification the potential level of output is not endogenously determined, and once full capacity utilization is achieved it is the rate of profit that determines the rate of accumulation and not the other way round. In addition, in the full capacity case, changes in effective demand lead to changes in income distribution, through changes in the price level. Similarly, the assumption of the tendency towards the level of normal capacity implies that there is an inverse relation between the rate of profit and the real wage rate. This is the result obtained by Joan Robinson when the rate of growth is higher than the rate of growth that corresponds to the minimum acceptable real wage inflationary pressures enter into the picture, further accumulation is precluded by the so-called 'inflation-barrier'. ${ }^{7}$

In that respect, the Kaldorian supermultiplier has the advantage that provides a theory of potential output, which is endogenously determined by autonomous spending. Technical progress and the inflation-barrier so to speak are endogenous to the model. The fundamental role of the Kaldor-Verdoorn's Law (KVL) is to endogenize the rate of growth of labor productivity. The way Kaldor made the rate of change of potential capacity endogenous was by using what became known as the KVL. The KVL suggests that there is a strong correlation between the growth of labor productivity and the rate of growth of economic activity. It is only with the KVL that the rate of growth, rather than the level of the productive capacity limit, is determined by autonomous demand. In that sense, the inflationary barrier, the

(1979), often emphasize the role of the external constraint. For a modern formalization of a supermultiplier model that does not limit autonomous demand to exports see Serrano (1995) and Bortis (1997).

\footnotetext{
${ }^{7}$ Inflation is in this view basically caused by demand-pull, associated to full capacity, even if the immediate or direct reason might be the incompatible income claims of workers and capitalists. Note that the type of inflation that Latin American economists suggested was relevant for the process of structural transformation of the economy was associated to the cost-push forces related to the inelasticity of food supply (e.g., Noyola-Vazquez, 1956). Later Structuralist models incorporated the effects of devaluations, associated to external crisis, and inertia caused by wage indexation. For alternative closures, and different inflation theories that allow for cost push reasons see Vernengo (2006b).
} 
capacity limit that if exceeded would lead to inflation, is endogenously determined by demand. As autonomous demand expands, the capacity limit moves further away.

This should not be interpreted as suggesting that demand-pull inflation cannot take place. If the rate of growth of demand outpaces the rate of growth of productivity the economy may very well hit the inflation-barrier. In other words, the question of whether there will be a correlation between inflation and unemployment will depend on the size of coefficients, which might vary from period to period. It must be noted, also, that under certain conditions expansionary demand may be perfectly compatible with price stability, and with an inflation-barrier that recedes as the economy grows.

Kaldor was interested in the relative decline of the UK and, as a result, measured the Verdoorn's Law in a cross-section of countries. He averaged out the rate of labor productivity and output growth between 1953-4 and 1963-4, and that was sufficient to deal with the cyclical fluctuation of both variables. This set the standards for the discussion and analysis of the KVL. However, nothing indicates that the KVL is not operational over time in a given economy. The reason for using a cross section of countries and averaging out the data over relatively long periods seems to be related to the need of dealing with the trend effects of output on productivity. If one were to measure the KVL in time series one would have to separate cyclical and trend effects. In that case, one must deal with the cyclical properties of labor productivity and output. It must be emphasized that the KVL when measured over time becomes intertwined with another well-known macroeconomic regularity, namely: Okun's Law. Okun argued that, in the United States, ' $[. .$.$] in the postwar$ period, on the average, each extra percentage point in the unemployment rate above four per cent has been associated with a three per cent decrement in real GNP' (Okun, 1962, p. 99). The relation implies that labor productivity, the ratio of output to employment is pro-cyclical. This suggests that the proper consideration of both regularities implies that Okun's Law deals with the cyclical characteristics of the relation between demand growth and labor productivity, while KVL is related to the trend or structural elements of the same relationship.

The incorporation of the KVL's effect into the long run supermultiplier model implies that not only employment and accumulation, meaning the level of full capacity output growth, but also the rate of change of the capacity limit, associated with productivity growth, is ultimately determined by demand forces. The Kaldorian model incorporating the supermultiplier and a theory of productivity growth provides a coherent alternative to the Ramsey-Solow-Lucas-Romer supply constrained approach to growth, and to the measurement of productivity. ${ }^{8}$

One important modification, in this sense, that it is possible to introduce in the

\footnotetext{
${ }^{8}$ Jeon and Vernengo (2008) show, for the United States between 1951 and 2005, a Verdoorn coefficient of approximately 0.63 and an Okun coefficient of around 1.69. The Keynesian interpretation suggests that both Okun's and Verdoorn's Laws imply causality from output growth to labor productivity, while conventional wisdom would suggest reverse causation.
} 
Robinsonian taxonomy of alternative Ages of capital accumulation, once the Kaldorian framework is used, is to scrap the problems associated with the disproportionality between the capital and consumer goods services, which are now ultimately resolved by the supermultiplier which guarantees that capital adjusts to the necessities of the desired level of accumulation. ${ }^{9}$ However, the Robinsonian preoccupation with sectorial proportionality might be brought back in another context. In particular, in the case of peripheral countries that are later in the process of capitalist development and industrialization, and for that reason require imports of intermediary and capital goods, there might be an incompatibility between the import profile, which we will assume is mostly associated with capital needs,,$^{10}$ and the ability to obtain foreign currency essentially by exporting. If the imports of capital are insufficient to provide capital compatible with the desired level of accumulation, then a national capital goods sector would have to be developed, and the proportion of this sector with respect to the domestic production of consumption goods would increase.

Under these assumptions, it is possible to suggest that if the proportion of the domestic capital goods sector were increasing, in what Structuralist economists referred to as the hard phase of industrialization, then we would be in an equivalent of the Robinsonian Galloping Platinum Age. On the other hand, if the imports of capital are sufficient to provide capital and to maintain the desired level of accumulation, then the national capital goods sector would have to be shrinking in proportion to the domestic consumption goods sector, and the economy would be in a Creeping Platinum Age. These problems of disproportionality, adapted for the situation of developing countries, suggest that external conditions, rather than strictly domestic ones are more important for explaining the traverse of the economy from one steady-state to the other.

Finally, although the inflation-barrier is in the view here discussed endogenous, it is still possible for the economy to reach its limits, and for incompatible income claims to lead to the building up of inflationary pressures. However, instead of a situation in which the profit rate cannot reach the desired level as a result of fuel employment, it is the external situation associated with a Galloping Platinum Age that would most likely lead to the breaching of the external constraint, followed by devaluation and inflationary pressures. If workers resist to devaluation, and demand higher wages, a foreign exchange-wage spiral might lead to high inflation.

\footnotetext{
${ }^{9}$ Note that this is a very different type of extension of the Robinsonian model that the one attempted Lovinsky and Gibson (2004) and Fuentes (ND).

${ }^{10}$ Several Latin American authors, some connected to ECLAC, suggested that national elites emulated the consumption patterns of developed countries. Excessive and superfluous consumption on luxuries would then reduce the potential for investment and capital accumulation. In other words, in this case imports would be tied not only to the needs of production, i.e., intermediary and capital goods, but would also be overburdened by the consumption needs of the most privileged in society. Kaldor also noted the same patterns when referring to developing countries. See, for example, Palma and Marcel (1989).
} 
On the basis of the modified Robinsonian taxonomy suggested in this section, a taxonomy or periodization of the process of development in Latin America is developed in the following section, starting with the post-war period, when explicit industrialization policies were, with varying degrees of intensity, applied throughout the whole region.

\section{AN ADAPTED ROBINSONIAN TAXONOMY FOR LATIN AMERICA}

The modified and simplified Robinsonian taxonomy for accumulation regimes as suggested in this paper, considers basically four different Growth Eras. The situation in which the desired capital accumulation is higher than the growth of labor supply can be seen as a Golden Age. ${ }^{11}$ This corresponds basically to the 1950s and early 1960s. The late 1960s and the early 1970s are a traverse period in which the process of industrialization accelerates, and the desired rate of accumulation is higher than the capital-requirements associated with potential growth, characterizing a Galloping Platinum Age. This pushes the needs for capital imports, and puts additional pressures on the balance of payments, which is the ultimate limit to the expansion of the economy.

\begin{tabular}{c|c|c}
\multicolumn{2}{c}{ Taxonomy of Accumulation Ages* } \\
\hline & \multicolumn{2}{|c}{ Desired Capital Accumulation } \\
\hline Labor Supply & Higher & Lower \\
\hline Capital Requirements & Golden Age & Leaden Age \\
\hline
\end{tabular}

* The taxonomy does not exhaust all the possibilities of an adapted Robinsonian classification of growth Ages. Source: Author

The lost decade of the 1980s could be considered a Leaden Age, in which the required capital accumulation was lower than the growth of labor supply. And the last two decades can be seen as a Creeping Platinum Age, a transition dynamics in which the desired rate of capital accumulation is lower than the capital-requirements, leading to a reduced need for capital formation, and reduced need for capital imports. This Creeping Platinum Age would be behind the process of reprimarization and deindustrialization in several economies in South America, and the maquilization of the economies of Central America and Mexico. ${ }^{12}$

\footnotetext{
${ }^{11}$ Note that it is a Golden Age even if the rate of growth is faster than the growth of the labor force. Still there are no labor shortages, which would be reasonable to expect in a region like Latin America with abundant labor surplus.

${ }^{12}$ Note that the Creeping Platinum Age, a phase of deceleration, refers not to a transition to a period of lower growth, since after 2002 economic growth accelerated in the wake of the terms of trade boom,
} 


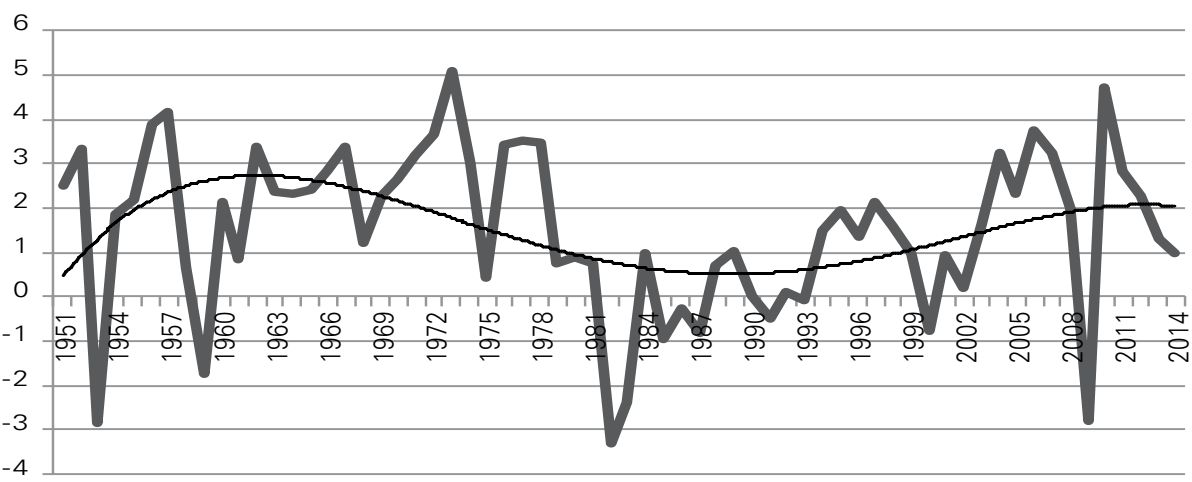

Source: Maddison.

The period of the 1950 s to the late 1960 s or early 1970 s, as much as in the rest of the world, is often referred to as a Golden Age. The graph below shows that the rate of economic expansion of per capita income in Latin America from 1950 to 2014 was on average at 1.5 percent, while in the sub-period from 1950 to 1973 it was around 2.2 percent. ${ }^{13}$ The Golden Age does not in this case perfectly correlate with Joan Robinson's notion of the theoretical Golden Age, and the causes for fast growth in the whole world and for the catching up of the periphery including Latin America, with the developed or advanced world are more complicated that can be discussed here. It is worth noticing that not only institutional factors, like the Bretton Woods arrangement or the expansion of Trade Union membership, but also geo-political elements associated to the Cold War, decolonization and military assistance played an important role in the exceptional rates of growth of that era.

Further, when we analyze at least two of the regularities described in the previous section, the notion that the level of investment is determined essentially by an accelerator, and that productivity is both pro-cyclical and pro-structural, meaning determined by Kaldor-Verdoorn's Law, we obtain preliminary results that seem to indicate that these propositions hold (Tables below).

but the transition to an economy in which capital accumulation and investment would be lower since the production and imports of capital goods are not required in the new steady state.

${ }^{13}$ That is if we take the conventional break of 1973 as the end of that Global Golden Age. Note that in 1973, after the military coup in Chile, and shortly after in the other Southern Cone countries, there is a move away from the industrialization policies of the $1950 \mathrm{~s}$ and 60 s. If alternatively we assume that the break for Latin America is better represented by the Mexican debt crisis of 1982, then the average rate of growth of income per capita remains unchanged at 2.2 percent. 


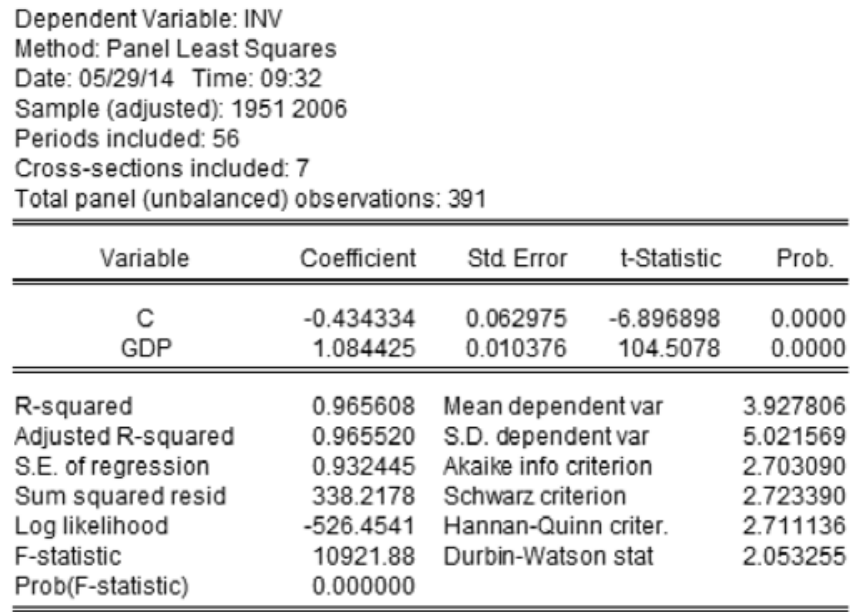

The first regression shows that investment is fundamentally explained by GDP growth, while the second shows that GDP growth is also central in the determination of the patterns of labor productivity growth. They provide, in a very broad sense, some evidence in favor of a Kaldorian closure for the demand driven growth model. Granger causality tests are inconclusive and do not provide further evidence on the relation between investment and economic growth. Note, however, that from a theoretical point of view there is little reason for a firm to invest unless it expects greater demand. The logical foundation of the accelerator seems to indicate that investment is ultimately derived demand.

\section{Kaldor-Verdoorn Law}

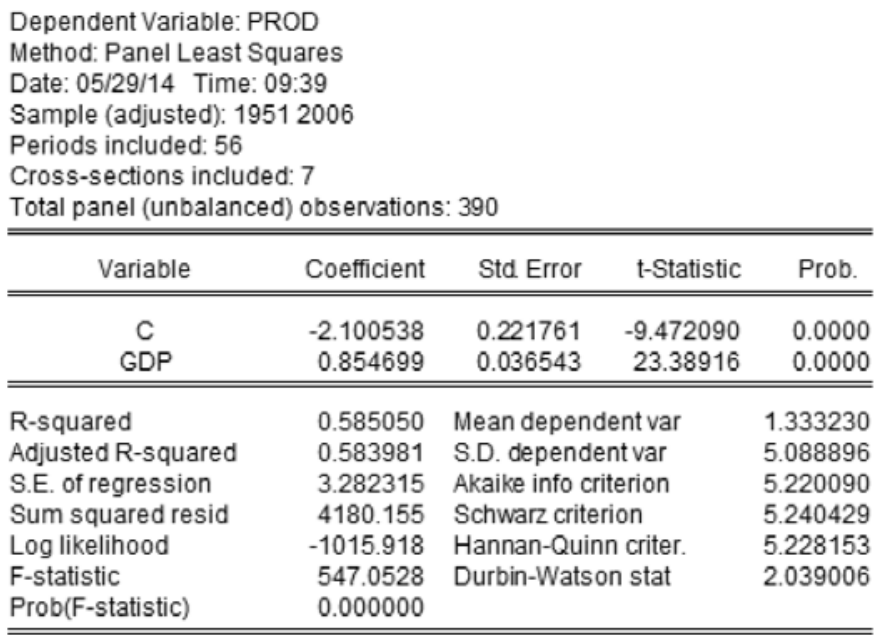


Another essential piece of information is the participation of the industrial sector, which dictates the needs of capital for the economy as a whole, in total value added. As it can be seen in the figure, the industrialization process peaked in the region as a whole in 1973, with manufacturing as a share of total value added climbing to around 22 percent of GDP in constant 1980 prices, and reaching around 30 percent in the most industrialized countries in the region, like Argentina and Brazil (Bértola and Ocampo, 2013, p. 168). From the late 1980s onwards, including the last phase, which corresponds to the commodity boom in the last decade, the share of manufacturing in total value added has contracted significantly returning to levels that are comparable with the early 1960 s.

Manufacturing value Added (\% GDP)

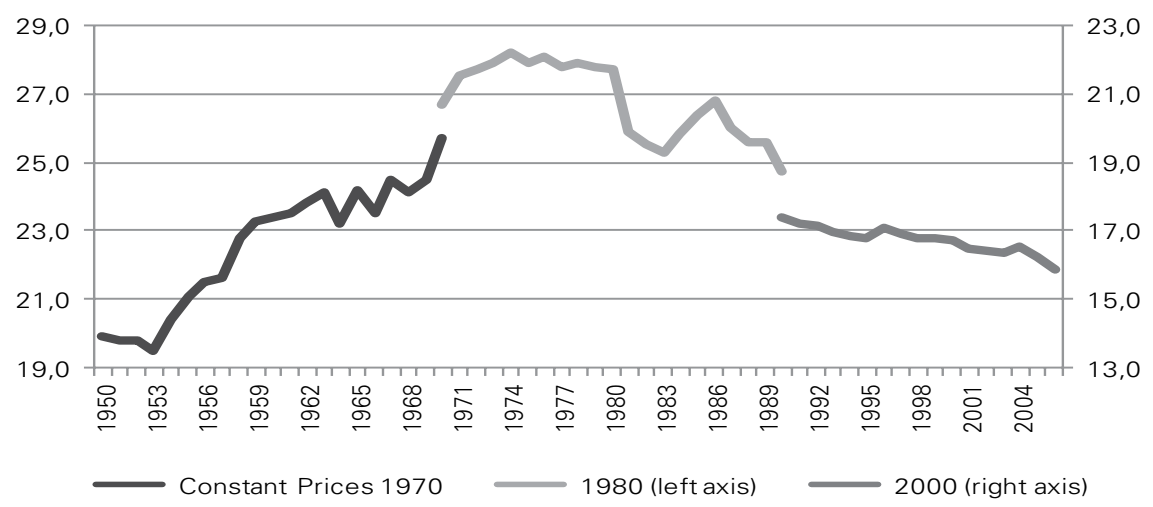

Source: Bértola and Ocampo.

Also, it is well-known that the process of industrialization in Latin America was concomitant with the existence of a significant amount of surplus labor, in the terminology of Lewis (1954). In other words, even though the accumulation of capital proceeded at a fast pace, again with varying degrees in different countries within the region, in the 1950s and 60s, population growth and the existence of a large pool of low productivity agricultural migrants, allowed for the continuous process of incorporation of the labor force in the modern industrial sector without creating any restriction. In this respect the 1950s and 60s can indeed be seen as a period equivalent to the Robinsonian Golden Age. Note that in some respects, the mismatch between the new demands of industrialization and the skills of the labor force, usually dealt with training programs heavily subsided by the State, led to the strengthening of the labor force, and while it would be an exaggeration to refer to this period as a Restrained Golden Age, it is not incorrect to assume that the desired rate of accumulation was growing faster than labor supply. The absence of labor shortages was possible only as a result of the large pool of low productivity workers in the primary sector. ${ }^{14}$

\footnotetext{
${ }^{14}$ At the same time that agricultural employment as a share of total employment fell from above $60 \%$
} 
Arguably, by the 1960 s, the easy phase of industrialization, consumer durables was over, and in a few countries the efforts for continued capital accumulation, faced with increasing demand for capital goods, and the declining external resources in proportion to the import requirements, led to the development of national capital goods sector, characterizing what may be referred to as a Galloping Platinum Age. In other words, the required rate of growth was higher than the current rate of growth of the capital goods sector and a tendency for balance of payments crises was increasingly likely, since the capital import requirements were not sustainable with the current level of exports. By the 1960s it was clear that the hard phase of industrialization would require, if an external crisis was to be avoided, an increase in the rate of growth of exports, and a diversification of the export profile of the region, still markedly dependent on commodities. ${ }^{15}$

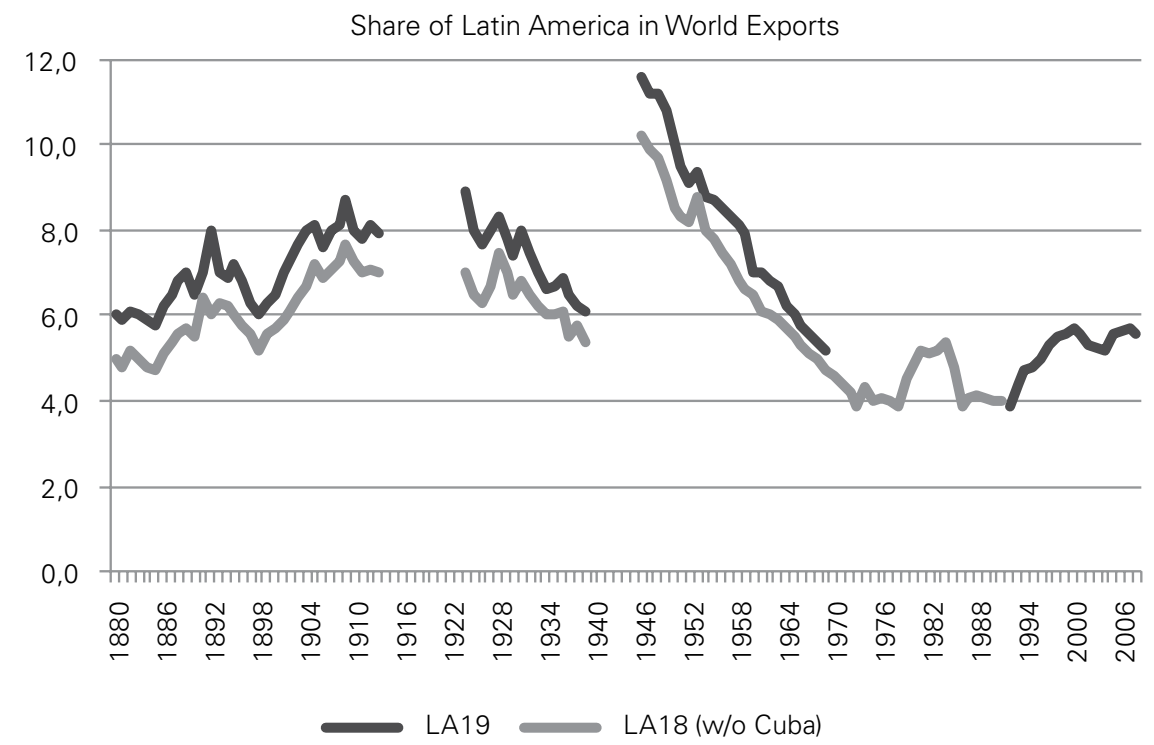

Source: Bértola and Ocampo.

in the 1950s to around high single digits or low double digits in the 2000s, the employment to population ratio grew from approximately $30 \%$ to slightly higher than $40 \%$ in the same period. However, levels of participation in the labor force are still considerably below developed countries, and informality in the labor market remains an important issue in Latin America.

${ }^{15}$ By the early 1960s, when he was leaving ECLAC and moving to UNCTAD, Prebisch's made it very clear that the Import Substitution Industrialization strategy with which ECLAC and himself were associated did not mean that exports were not important. In fact, the first UNCTAD report was concerned that the protectionism of developed countries precluded the increase in exports in the periphery that would allow for balanced external accounts. Not long after this Aníbal Pinto developed the notion of structural heterogeneity, which suggested that even with industrialization the transformation of the structure of the economy remained incomplete. Manufacturing production was essentially for domestic markets (or for other markets in the region), while the main exports remained associated to traditional commodities. 
In some countries, particularly Brazil among the most successful industrializers some policies to encourage export orientation were implemented by the late 1960s, with special lines of credit and industrial policies favoring access to external markets. Yet in spite of the understanding of the importance of exports to avoid balance of payments crisis, there was a chronic inability to expand and diversify exports. The figure shows that by the 1970s the share of Latin American exports in world exports had decreased significantly from its peak at the height of World War II. Even if one discounts the heightened levels of World War II (Bertola and Ocampo, 2013, p.24), the export share by the 1970s was below the levels of the commodity boom during the Belle Époque.

The shrinking of the export share, combined with the double shock of higher rates of interest and lower commodity prices in the 1970s led to the infamous debt crisis. It is important to note that the process of industrialization commanded by the State or the Import Substitution Industrialization cannot be considered the main cause of the Debt crisis of the 1980s.

The 1970s resolved the inconsistencies of the Galloping Platinum Age with increasing indebtedness, which was made possible by the collapse of Bretton Woods, the oil shocks and the recycling of the petro-dollars. Crises are usually catalysts for change, and debt crises are no different. The wide spread debt crisis in what used to be called the Third World - in particular in Latin America - in the 1980s corresponds to a period of transition in the cycles of State intervention. In Latin America the reinvigorated role of the State after the depression of the 1930s took the form of an Import Substitution development strategy. The Latin American debt crisis is the landmark that divides the Import Substitution Industrialization (ISI) strategy, devised under the intellectual guidance of the Economic Commission for Latin America and the Caribbean (ECLAC), and the market friendly approach, institutionalized by the International Monetary Fund (IMF) and the World Bank.

Initially several commentators presumed that the effects of the debt crisis would be temporary, and growth would resume since the traditional solutions, adjustment and finance, would be effective in surmounting what was seen as a short-lived balance of payments crisis. There is a fundamental difference between crises where a country's underlying debt position is sustainable over the long run and those where debt restructuring is unavoidable. Many thought that the crisis unleashed by the Mexican default of August 1982 was of the former type.

The crisis, however, was more lasting and acute than expected, and, in fact, the 1980s became known in Latin America as the lost decade. By the mid-1980s most analysts were certain that the crisis was going to be long lived and some argued that a radical change in the development strategy was necessary. The policies that were suggested - and then imposed in the context of international agreements - and that eventually became known as the Washington Consensus (Williamson, 1990), are, therefore, the result of need for a new development strategy. In many respects, 
the crisis of the developmental State, and the Debt Crisis represent for Latin America what the so-called fiscal crisis of the State does for the developed world. In that respect, the market friendly approach to development is the other face of the conservative revolution of Reagan and Thatcher in the developed world.

Capital flows to the developing world in the last financing cycle, in particular to Latin America, started before the 1970s. Foreign Direct Investment (FDI) flows in the 1950s, official aid flows in the 1960s - linked to the Alliance for Progress - preceded the private capital flows of the 1970s that took the form of bank loans. Conventional wisdom presupposes that from World War II to the debt crisis - during the ISI period - economic policies were focused on domestic markets, and an anti-export bias was developed. The ISI strategy was characterized by high levels of import tariffs and a relatively high dispersion of the tariff structure protecting domestic production, an overvalued exchange rate discriminating against the exports of primary goods and favoring the imports of intermediate and capital goods. The rate of growth was as a result highly dependent on the expansion of domestic demand. Conventional wisdom presumes that government spending crowded-out private investment, and that protectionism meant that inefficiencies abounded.

In this view, the results were the accumulation of trade and fiscal deficits, and the pilling up of debt. In addition, the investment effort was beyond the fiscal capacity of the State. Foreign savings provided the necessary finance for the development strategy, but when the unsustainability became clear then capital flows dried up and the debt crisis ensued. In addition, the response to the oil shock is seen as an important cause of the debt crisis. For most non-oil exporter countries in the periphery the oil shocks meant increasing trade deficits. There are basically two solutions for the problem. If the deficits are deemed temporary one may finance the short lived balance of payments disequilibria. On the other hand, if deficits are seen as long-lived, then adjustment - depreciation and lower rates of growth - is needed to contain the deficit from ballooning.

The other consequence of the oil shocks of the 1970s was the creation of large trade surpluses for the OPEC countries. These dollar surpluses were deposited in the Euro-dollar market, providing a huge amount of liquidity into a deregulated market. Interest rates became negative, and, as a result, the finance option became far more attractive than the adjustment one for developing countries. Further, international financial markets forcefully tried to push loans to developing countries. In this view then countries continued to pursue ISI development strategies, and were able to do it because of favorable conditions in international financial markets. However, negative terms of trade shock and an additional interest rate shock made the strategy unsustainable. The Mexican default of August 121982 was, then, the result of a misguided development strategy, and the ultimate solution depended on adopting a new one.

The problem with the conventional wisdom is that the ISI period corresponds to a high growth phase for most developing countries, one in which they catch 
up with the developed world despite the fast growth in the latter. In fact, Rodrik (1999, p. 71) argues that "contrary to received wisdom, ISI-driven growth did not produce tremendous inefficiencies on an economy wide scale. In fact, the productivity performance of many Latin American and Middle Eastern countries was, in comparative perspective, exemplary". Furthermore, several countries had already abandoned ISI policies in the 1970s. The Southern Cone countries had moved into neo-liberal policies by the mid-1970s, Brazil and many South East Asian countries were experimenting, with varying degrees of success, with export oriented strategies.

The ISI period, which basically corresponds to the 1950s and 60s, led to only moderate accumulation of foreign debt, and in many cases to falling debt to GDP or debt to exports ratios, which denotes sustainable debt dynamics. Hence, ISI policies, and the fiscal consequences of those policies seem to be of secondary importance in explaining the debt crisis.

In some countries, particularly in the Southern Cone, a calculated decision to reverse industrialization policies and revert to international integration on the basis of comparative advantage, with a significant process of liberalization was set in motion, while others, like Brazil tried to speed up and deepen the industrialization process. ${ }^{16}$ However, independently of the strategy followed in the 1970s, once confronted with the Volcker shock, and the higher rates of interest, worsened by a negative terms of trade shock, all the economies in the region collapsed and spent the next decade, the so-called lost one, dealing with the problems of debt default and renegotiation that would eventually lead to the acceptance of the Washington Consensus policies, and the abandonment of the industrialization project of the National Developmentalist Era.

The 1980s can be seen clearly as a Leaden Age, in which the rate of capital accumulation is well below the rate of growth of the labor force. As such, not only the formal labor market was unable to incorporate the growing labor force, but the large pool of rural workers that had for the most part migrated to cities in large numbers from the 1930s until the 1980s increased the ranks of the unemployment. Disguised unemployment, that is, the workers holding low productivity jobs, swelled. Note that the end of the Golden Age, in this sense, was not caused by the domestic market limits to the process of accumulation, but was a side effect of the collapse of the global economic order the underpinned the process of accumulation, and that was manifested in Latin America as the unsustainable service of foreign denominated debt.

The long process of renegotiation of debt, which eventually was accomplished with the Brady Plan, and the ideological turn associated to the Conservative Revolution in advanced countries and the collapse of the Soviet bloc, eventually led to

\footnotetext{
${ }^{16}$ It is interesting to note that the debt crisis also hit oil exporting countries like Mexico and Venezuela, which might have experienced a bout of the Dutch Disease, with negative long-term consequences for development.
} 
the liberalization policies of the 1990s and the so-called Washington Consensus (Williamson, 1990; Camara and Vernengo, 2002-3), which basically created the conditions for a Creeping Platinum Age, or in other words, a situation in which the desired rate of accumulation of capital was below the requirements of imported capital, and a process of deindustrialization, with a significant reduction of the capital goods sector and a reduction of the levels of manufacturing employment, took place.

The prolonged Creeping Platinum Age led to a new pattern of export specialization (commodities in South America) and 'maquilas' in (Central America and Mexico), and what might be seen as a New Development Strategy or a new division of labor within the region that superseded the State-led Industrialization policy of the 1950s to the 1970s. Central American and Caribbean countries and Mexico are more dependent on exports of manufacturing commodities, with low levels of domestic value added, and on remittances, something that has been as the 'export of people' (Pérez Caldentey and Vernengo, 2010), while South America has reoriented its economies towards a resource based model.

The risks associated with the New Development Strategy, which is associated in many ways to the rise of China as a global economic powerhouse, is associated to the same old limitations of the old commodity export model, namely the heavy dependence on the volatility of commodity prices and of remittances and other capital flows. It is important to note, also, that the greater integration with China has been dominated by a small number of commodities and a few countries. Five countries (Argentina, Brazil, Chile, Colombia and Peru) and eight sectors - essentially metals, including iron ore and copper, accounting for nearly half exports, soybean and related oils, and crude oil - generated just over 80 percent of all regional exports to China (Gallagher and Porzecanski, 2010). In other words, in terms of the composition of exports to China, the region's role is clearly as a supplier of primary products and resource based manufactures with a relatively low degree of value added. It is also wroth noticing that China is becoming increasingly more relevant as a destination for Latin American exports, and that the regions' exports to China are much more heavily concentrated on primary products and resource based manufactures than the region's exports to the rest of the world (Jenkins, 2009). The pattern of imports from China is the reverse of that noted for Latin American exports to China. Almost all Latin American imports from China are manufactured goods and the vast majority is non-resource based manufactures, with only a small proportion of imports from China being of lowtech goods (Ibid.).

The new pattern of specialization and the increasing integration with China has led to an increase in the trade imbalances, which seemed to have affected Mexico and the countries of the Central American Free Trade Area (CAFTA) more heavily than the South American countries, as can be seen in the figure. 


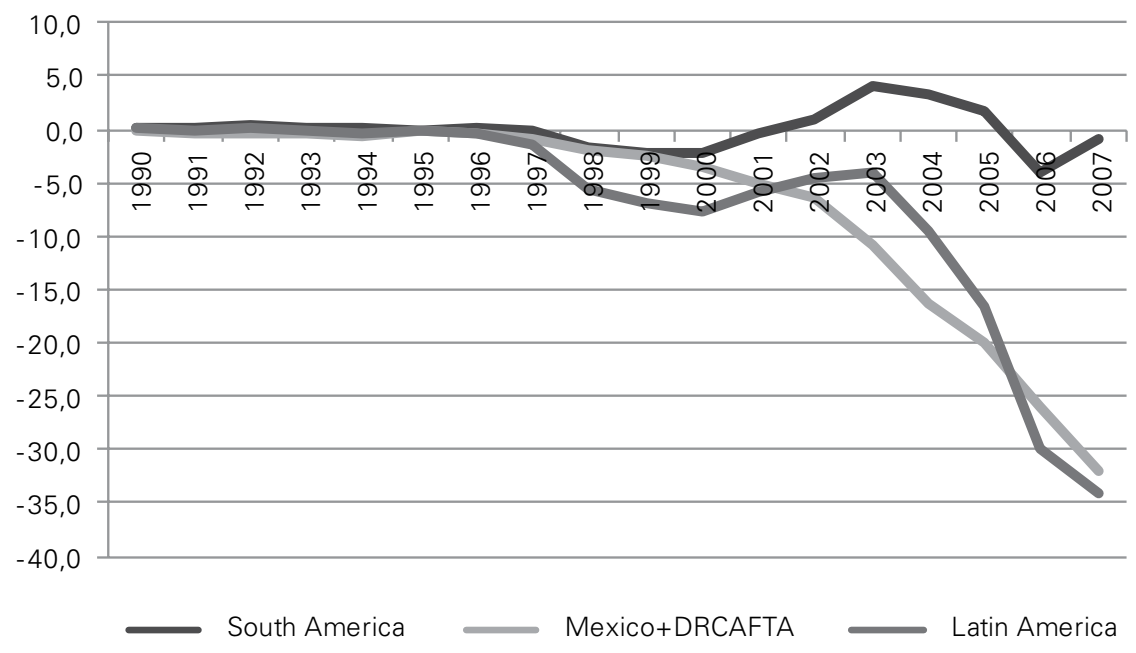

Source: Jenkins.

The limits of the current development strategy are associated, not only to the patterns of specialization, which promote production in less technologically dynamic sectors, but also to the possibility of the end of the super-cycle of commodities (Erten and Ocampo, 2013). Note that while China is central for the boom in commodity prices during the last decade, its impact has been exaggerated. While China accounts for approximately more than half of world's consumption of iron ore, a third of aluminium and zinc, and more than a quarter of copper, and is a major source of demand for certain agricultural products, particularly soybeans, soybean oil and fishmeal, making up approximately a fifth of world consumption, in other commodities, like beef and poultry, crude oil and tropical agricultural products such as sugar, bananas and coffee, its share of world consumption is such that variations of demand cannot be the main driving force behind short-term prices.

Erten and Ocampo (2013) argue that commodities prices have gone over long cycles, which are not completely dissimilar to the Kondratiev and Schumpeter's long waves, and that we might be at the end of the boom phase of such a process (see Figure below). Note that the super-cycle does not preclude the possibility of a negative trend, which is still visible over the whole of the $20^{\text {th }}$ Century, with the negative implications suggested by Raúl Prebisch in his 'Development Manifesto'. 


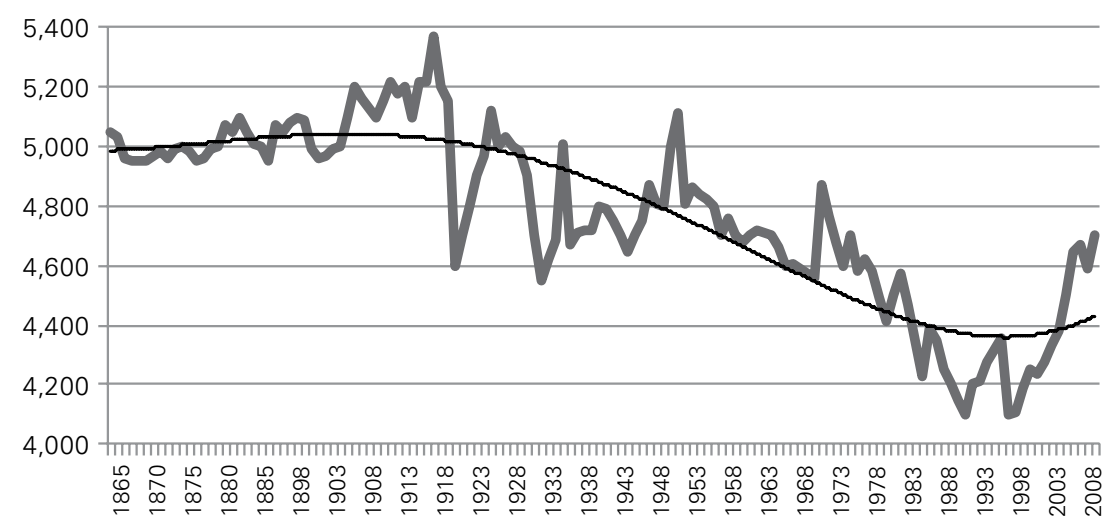

For our purposes what matters is that the possible collapse of commodity prices might have a significant impact on the current Latin American development strategy. From the point of view of the Robinsonian adapted taxonomy adapted here, it is important to note that the reprimarization and maquilization process, which has involved a certain degree of deindustrialization, with lower levels of manufacturing employment corresponding to particular levels of GDP per capita, explains why the desired rate of accumulation of capital has been below the capital requirements (Tregenna, 2011; Palma, 2013). Further, from a Kaldorian point of view, the manufacturing sector is essential for the process of economic growth and technological innovation. In that sense, the Creeping Golden Age is doubly problematic, since it leads to the possibility of increasing volatility associated to fluctuations of commodity prices, and also leads to a less dynamic process of capital accumulation and technological transformation. ${ }^{17}$

Yet, it is important to note, in spite of the limitations of the current development strategy, that over the last decade improvements in income distribution and poverty, and the expansion of social policies that made those advances possible, might also have an impact on the process of accumulation. Note that, in part, the expansion of social policies was associated to the wider control of the State on national resources, directly by expanding ownership or indirectly by increasing the tax burden on private owners, what has been referred to as Natural Resource Nationalism, or sometimes in a more narrow sense Petro Populism (Parenti, 2005). In that sense, the role of income distribution in the adapted Robinsonian taxonomy

\footnotetext{
${ }^{17}$ Katz and Stumpo (2001) argued that technological capabilities and production linkages diminished throughout the 1980s and 1990s in Latin America, and that research and development (R\&D) expenditures were cut. This was to some extent the result of a deterioration of the institutional capabilities within the public sector.
} 
is discussed in the next section, with particular emphasis on the last decade, in which income distribution has improved in the region, while in most of the rest of the world, in particular in advanced economies, inequality has increased (Galbraith, 2012; Piketty, 2014).

\section{THE TAXONOMY OF ‘GROWTH ERAS’ AND INCOME DISTRIBUTION}

The Latin American economic expansion since 2002 does not result uniquely from specific government policies, even though some left of center governments have tried to implement alternatives to the Washington Consensus. The empirical evidence suggests that the good economic performance of the 2003 2008 period was increasingly and strongly correlated either with a positive termsof-trade shock, mostly in South America, or with the increase in the flow of remittances, particularly in Central and North America (Pérez Caldentey and Vernengo, 2010).

The current economic boom shares with the old agro-export model of the $19^{\text {th }}$ and early pre-WWII $20^{\text {th }}$ century the fact that one of the dynamic elements is external demand, and, as a result, subject to the same risks of external shocks. Also as occurred in the agro-export model, financial factors shape and determine the pattern of productive specialization in Latin America. There is, however, an important difference with the development model of the Belle Époque or the early preWWII $20^{\text {th }}$ Century. While immigration was integral to the late $19^{\text {th }}$ century boom, and as noted above migration policies could hardly be implemented at the beginning of the $20^{\text {th }}$ Century, the $21^{\text {th }}$ century economic boom has been related for some economies to significant emigration. As noted before, Latin America now exports commodities and people. The current development model applies the logic of integration into international markets to its full extent and perfects the old agro-export model. As a result, Latin America specializes in the exports of its abundant factors, natural resources and labor.

A second essential difference in the current period is the significant improvement in different measures of income inequality (ECLAC, 2010). The positive trend in income distribution in Latin America during the commodity boom from 2003 to 2008 was linked primarily to the labor market dynamics. Both the increase in the proportion of formal, high-quality and full-time jobs, and more active policies for raising minimum wages probably favored this outcome. In a sense, the commodity boom, and the higher rates of growth have gone hand in hand with improved income distribution, and, in general higher real wages, and higher (at least considering the low levels of the early part of the $21^{\text {st }}$ Century) wages shares. According to Cornia (2014) the average regional Gini coefficient declined from 54.1 in 2003 to 48.6 in 2010, bringing it back to the early 1980s levels, a period that 
preceded the debt crisis and the lost decade of the 1980s, and the neoliberal reforms of the 1990s.

The question, then, is whether Latin America can be classified as having a wage-led regime. It is worth noticing that while real wages have increased and the wage share in total income has also expanded in many countries in the region, it is also true that the profit rate has also seen a recovery. Beyond the questions about whether the rate of profit or the profit share should be used to understand the possibility of profit-led regime, there is the theoretical limitation of the profit-led closure itself, in particular the causality question, i.e., whether the profit rate causes or is caused by the process of growth and capital accumulation.

It is important to note that Robinson's original banana diagram model did not allow, like the Kaleckian model, for the distinction of distributive regimes, with profit-led regimes ruled out. It is only with later formalizations of the model, in particular Marglin and Bhaduri (1990) that the possibility of the latter was brought into the picture. In other words, Robinson $(1956,1962)$ clearly assumed that while expected profits had an impact on capital accumulation, at the end of the day, the profit rate was determined by autonomous spending, and animal spirits, and were the result of capital accumulation, as in the Kaleckian dictum, according to which capitalists earn what they spend.

Even if the increase in the rate of profit is correlated with an acceleration of economic growth, this is not incompatible with an acceleration of real wage growth, and as a result one cannot conclude that the economic system in the region is profit or wageled. Given the strength of the accelerator results discussed before, however, it seems reasonable to argue that causality runs from growth to income distribution.

It is important, given possible causality ambiguities, to understand the relation between income distribution and accumulation to look beyond the statistical evidence, and appreciate the overall reasons for why the current development strategy seemed to be so successful during the boom period, between 2003 and 2008. The favorable external conditions, first and foremost the higher prices of commodity prices, but also the relatively liquid international financial markets, with low rates of interest in the center, provided the conditions for the expansion. ${ }^{18}$ Income redistribution, associated to improved labor market conditions and social policies, provided an additional source of demand, which might be the cause behind the expansion of profits.

\footnotetext{
${ }^{18}$ Ben Bernanke has suggested that low interest rates were possible as a result of more efficient central banks, and the so-called Great Moderation. More plausibly the 'Moderation' results from lower levels of unionization, and less wage resistance by workers facing a globalized economy, in which outsourcing is a plausible threat. Further, the low rates of interest are more likely connected to the sequential bursting of bubbles, the Junk Bonds and Savings \& Loans crisis of the late 1980s, the dot.com of the 1990s, and the housing bubble in the 2000s.
} 
One would assume that higher levels of economic growth and capital accumulation, concomitant with higher profits would lead to a reversal of the conditions that led to the so-called Creeping Platinum Age. In other words, under circumstances that allow for the expansion of consumption, given higher real wages, and positive expectations about growth, one could conceivably expect that there would be an increase in the demand for machines, and a relative expansion of the capital goods sector, which should lead to higher external pressures, everything else constant. That is, reindustrialization and a return to a Galloping Platinum Age, in which a large part of investment would be devoted to enlarging the capital goods sector (or importing equipment), and the gallop would lead to an inflation barrier, which would slowdown the rate of accumulation.

Certain authors, in particular those associated with what Bresser-Pereira (2010) has referred to as the New Developmentalism (e.g., Frenkel and Rapetti, 2012), have suggested that the risks of the current development strategy are associated to appreciated real exchange rates (high real wages), that, in their view lead to deindustrialization, ${ }^{19}$ and to excess demand, associated not only to higher wages and consumption (or imported investment goods), but also to fiscal deficits, and inflation acceleration. In this view, the limits to the Latin American boom would be associated to the infamous inflation barrier, so to speak. In some countries austerity policies have been implemented on the basis of this view.

It is worth discussing the implications of the inflation barrier in an open economy in the modified Robinsonian taxonomy of Growth Ages here proposed. Note that while formal employment grew in the last boom, there is a chronic problem of incorporating surplus labor in the region, which has not yet been solved. In that sense, the economy is not truly at full employment, even if open unemployment levels are low in many countries. Also, the timing of the deceleration has been clearly correlated to the Global Financial Crisis, the decline in commodity prices, the long stagnations that has befallen the European economies, and the slowdown of China, India and other high growing Asian economies, which still grow fast, but at a reduced pace.

While it is true that real wage expansion and real exchange appreciation have gone hand in hand with worsening external conditions, with the brief trade (and current account) surplus vanishing by the latter part of the boom, it is also true that the evidence for a positive effect of devaluation (and lower real wages) on the external conditions is essentially related to income rather than price elasticities. ${ }^{20} \mathrm{In}$ this sense, the inflationary pressures come less from the fact that the economy is

\footnotetext{
${ }^{19}$ This deindustrialization had been seen, together with the reprimarization of exports, as evidence of a Dutch Disease (Bresser-Pereira, 2010).

${ }^{20}$ There is an extensive and well-known literature on the subject, starting with the work by DíazAlejandro on the contractionary effects of devaluation in Argentina, to the formalization of these ideas
} 
close to full employment, but from the fact that wage resistance and other cost-push factors have had an impact. Further devaluation would not solve the limitations of the current development strategy, while it would exacerbate the inflationary pressures already present in some countries in the region. ${ }^{21}$

In that sense, it is possible to suggest that like in Joan Robinson's Bastard Golden Age, the rate of accumulation is held in check by a financial restriction (in this case mostly an external one) that is not associated to labor scarcity or to the full utilization of resources. The external constraint barrier, might very well lead to exacerbated distributive conflict and inflationary pressures, but unlike the inflation barrier does not imply that the economy has reached its capacity limit.

\section{CONCLUDING REMARKS}

This paper suggests that, using a modified taxonomy of Growth Eras, Latin America has moved from a Golden Age in the 1950s and 1960s, to a Leaden Age in the 1980s, having two traverse periods, one in which the process of growth and industrialization accelerated in the late 1960s and early 1970s, which is here referred to as a Galloping Platinum Age, and one in which a process of deindustrialization, and reprimarization and maquilization of the productive structure took place, starting in the 1990s, which could be referred to as a Creeping Platinum Age. Note that the Creeping Platinum Age might not necessarily imply low growth, and in fact most of the region has experienced at least during the commodity boom after 2003 relatively high levels of growth. However, in terms of capital accumulation, that is, in terms of investment, industrial capacity and the industrial value added of exports the Creeping Platinum Age has been one of deceleration of the process of industrialization in the region. In other words, both the reprimarization of exports in South America, and the maquilization of exports in Central America and Mexico are part of a process of rearranging of the world's international division of labor in which increasingly manufacturing moves towards the Asian periphery.

Also, the Galloping Platinum Age was not without limitations. The traverse towards a more industrialized economy led to higher rates of capital accumulation, which exacerbated the external constraints of the economies in the region, and by strengthening the labor force, led to inflationary pressures. Note that the collapse of the Galloping Platinum Age, however, was ultimately brought about by the

by Paul Krugman and Lance Taylor. For a more recent formalization see Pérez Caldentey and Vernengo (2013).

${ }^{21}$ For a discussion of the effects of devaluation and real wage resistance on inflation, an old idea discussed by Latin American Structuralists; see Vernengo (2006b). 
double shock of higher international interest rates and lower commodity prices, which created the conditions for the Debt Crisis of the 1980s.

The current Creeping Platinum Age is also a traverse in which the investment sector is greater than what is needed for the possible rate of growth. The limits to the current Growth Era are less associated to an inflation barrier, even a modified inflation barrier in which balance of payments constraint and distributive conflict rather than full capacity utilization are the source of inflation, and essentially connected to the negative effects of deindustrialization on productivity growth, and the excessive reliance on volatile commodity prices and capital flows (in particular, remittances) to finance external imbalances. The risk, so to speak, is to promote a peripheral integration into the world economy, now with the Asian periphery, rather than with the center as happened in the Belle Époque.

\section{REFERENCES}

Bértola, L. and J. A. Ocampo (2013), The Economic Development of Latin America since Independence. New York and Cambridge: CUP.

Bhaduri, A. and S. Marglin (1990), "Unemployment and the Real Wage: The Economic Basis for Contesting Political Ideologies,” Cambridge Journal of Economics, 14, pp. 375-393.

Blecker, R. (1989), “International Competition, Income Distribution and Economic Growth,” Cambridge Journal of Economics, 13, pp. 395-412.

Bortis, H. (1997), Institutions, Behaviour and Economic Theory: A Contribution to Classical-Keynesian Political Economy. Cambridge: CUP.

Bresser-Pereira, L. C. (2010), Globalization and Competition. Cambridge: Cambridge University Press. Camara Neto, A. F. and M. Vernengo (2002-03), "Globalization, a dangerous obsession: Latin America in the Post-Washington Consensus Era," International Journal of Political Economy, 32(4), Winter, pp. 4-21.

Cornia, G. A. (2014), “Recent distributive changes in Latin America: An overview.” In G. A. Cornia (ed.), Falling Inequality in Latin America: Policy Changes and Lessons. Oxford: Oxford University Press.

Dosi, G., G. Fagiolo, and A. Roventini (2008), “Schumpeter meeting Keynes: A policy-friendly model of endogenous growth and business cycles," Journal of Economic Dynamics \& Control, 34, pp. 1748-1767.

Dutt, A. (1990), Growth, Distribution and Uneven Development. Cambridge: CUP.

Erten, B. and J. A. Ocampo (2013), "Super cycles of commodity prices since the mid-nineteenth century,” World Development, 44, pp. 14-30.

Frenkel, R. and M. Rapetti (2012), "External fragility or deindustrialization: what is the main threat to Latin American countries in the 2010s?” World Economic Review, No 1, pp. 37-56.

Fuentes, J. A. (ND), "Hacia una interpretación robinsoniana de la acumulación de capital en América Latina," ECLAC, processed.

Galbraith, J. (2012), Inequality and Instability: A Study of the World Economy Just Before the Great Crisis. New York: Oxford University Press.

Gallagher, K. and R. Porzecanski (2010), The Dragon in the Room: China and the Future of Latin American Industrialization. Redwood City, CA: Stanford University Press.

Jenkins, R. (2009), “The Latin American case.” In R. Jenkins and E. Dussell-Peters (eds.), China and 
Latin America: Economic Relations in the Twenty-First Century. Bonn: Deutsches Institut für Entwicklungspolitk.

Jeon, Y. and M. Vernengo (2008), “Puzzles, paradoxes, and regularities: cyclical and structural productivity in the United States (1950-2005)," Review of Radical Political Economics, 40(3), Summer, pp. 237-243.

Kaldor, N. (1970), “The case for regional policies," Scottish Journal of Political Economy, 17(3), pp. 337-348.

Katz, J. and G. Stumpo (2001), "Regímenes sectoriales, productividad y competitividad internacional,” Revista de la CEPAL, No 75, pp. 137-159.

Lavoie, M. (1992), Foundations of Post Keynesian Economics. Aldershot, Edward Elgar.

Lewis, W. A. (1954), "Economic development with unlimited supplies of labour," The Manchester School, 22(2), pp. 139-191.

Lovinsky, J. and B. Gibson (2004), “A Robinson model for Argentina.” In B. Gibson (ed.), Joan Robinson's Economics: A Centennial Celebration. Cheltenham: Edward Elgar.

Maddison, A. (2001), The World Economy: A Millennial Perspective. Paris: OECD. <http://www. theworldeconomy.org/>

Noyola-Vázquez, J. (1956), “El Desarrollo Económico y la Inflación en México y otros Países Latinoamericanos,” Investigación Económica, XVI: 4, pp. 603-616.

Okun, A. (1962), “Potential output: Its measurement and significance.” In American Statistical Association, Proceedings of the business and economics section. Washington, DC: American Statistical Association.

Palma, G. (2013), “De-industrialization, 'premature' de-industrialization and the Dutch Disease.” In S. Durlauf and L. Blume (eds.), The New Palgrave Dictionary of Economics Online. <http://www. dictionaryofeconomics.com/article?id=pde2008_D000268> doi:10.1057/9780230226203.0369

Palma, G. and M. Marcel (1989), "Kaldor on the 'discreet charm' of the Chilean bourgeoisie," Cambridge Journal of Economics, 13(1), pp. 245-272.

Parenti, Ch. (2005), "Hugo Chávez and petro populism,” The Nation, April 11, pp. 15-21.

Pérez Caldentey, E. and M. Vernengo (2010), "Back to the future: Latin America's current development strategy,” Journal of Post Keynesian Economics, 32(4), 2010, pp. 623-644.

Pérez Caldentey, E. and M. Vernengo (2013), "Wage and profit-led growth: the limits to neo-Kaleckian models and a Kaldorian proposal,” Economics Working Paper No 775, Levy Economics Institute.

Piketty, Th. (2014), Capital in the Twenty-First Century. Cambridge, MA: Harvard University Press.

Robinson, J. (1956), The Accumulation of Capital. London: Macmillan.

Robinson, J. (1962), Essays in the Theory of Economic Growth. London: Macmillan.

Rodrik, D. (1999), “The new global economy and developing countries: making openness work.” Overseas Development Council, Policy Essay No. 24. Washington DC: ODS.

Rowthorn, R. (1981), "Demand, real wages and economic growth.” Thames Papers in Political Economy, Autumn: pp. 1-39.

Serrano, F. (1995), "Long period effective demand and the supermultiplier," Contributions to Political Economy, 14, pp. 67-90.

Taylor, L. (1985), “A stagnationist model of economic growth,” Cambridge Journal of Economics, 9(4), pp. 383-403.

Taylor, L. (2004), Reconstructing Macroeconomics. Cambridge: Harvard University Press.

Thirlwall, A. P. (1979). "The balance of payments constraint as an explanation of international growth rates”, Banca Nazionale del Lavoro Quarterly Review, 128, pp. 45-53.

Tregenna, F. (2011), "Manufacturing productivity, deindustrialization, and reindustrialization," UNU-WIDER, Working Paper No. 2011/57. 
Vernengo, M. (2006a), “Technology, finance, and dependency: Latin American radical political economy in retrospect," Review of Radical Political Economics, 38(4), Fall, pp. 551-568.

Vernengo, M. (2006b), “Money and inflation.” In P. Arestis and M. Sawyer, A Handbook of Alternative Monetary Economics, Cheltenham, Edward Elgar, pp. 471-489.

Vernengo, M. and L.-P. Rochon (2001), "Kaldor and Robinson on money and growth," European Journal of the History of Economic Thought, 8(1), Spring, pp. 75-103.

Williamson, J. (1990), "What Washington means by policy reform.” In J. Williamson (ed.), Latin American Adjustment: How Much Has Happened? Washington, DC: Institute for International Economics. 